\title{
Asymmetric and Regiospecific Synthesis of Isotopically Labelled Cyclopropane Fatty Acid (9R,10S)-Dihydrosterculic Acid: Overcoming Spontaneous Protonation During Lithium-Sulfoxide Exchange
}

\author{
Samuel W. J. Shields ${ }^{\mathrm{a}}$ \\ Peter H. Buist ${ }^{\mathrm{a}, \mathrm{b}}$ \\ Jeffrey M. Manthorpe ${ }^{* a, b}$ (i) \\ a Carleton University, Department of Chemistry, 203 Steacie \\ Building,, 1125 Colonel By Drive, Ottawa, Ontario, K1S 5B6, \\ Canada

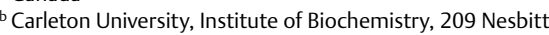 \\ Building, 1125 Colonel By Drive, Ottawa, Ontario, K1S 5B6, \\ Canada \\ jeff.manthorpe@carleton.ca
}

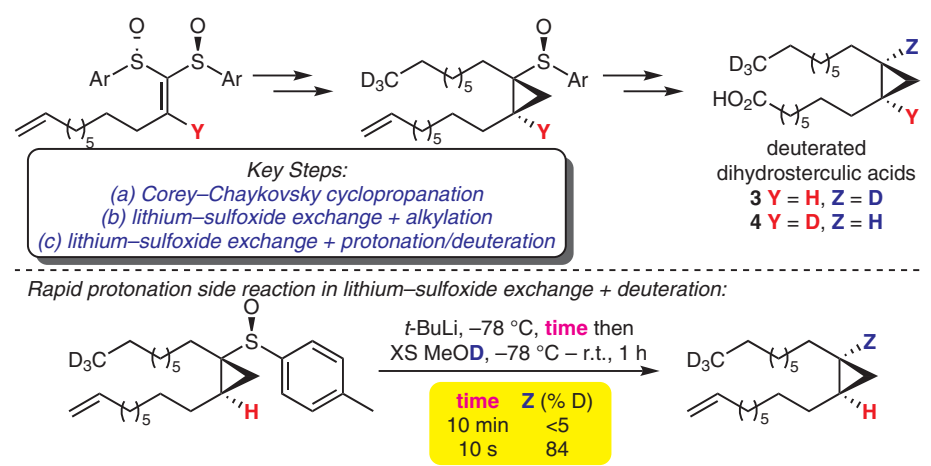

Received: 12.01.2018

Accepted after revision: 14.03.2018

Published online: 08.06 .2018

DOI: 10.1055/s-0036-1591976; Art ID: so-2018-d0004-op

License terms: cc)

Abstract The total synthesis of isotopically labelled $(9 R, 10 S)$-dihydrosterculic acid, a usual cyclopropane fatty acid with biologically relevant toxicity upon desaturation in vivo, is reported. A diastereoselective Corey-Chaykovsky reaction was employed to form the cyclopropane ring. Rapid quenching of a lithium-sulfoxide exchange was required to achieve the requisite high levels of deuterium incorporation.

Key words lithium-sulfoxide exchange, deuterium labelling, asymmetric Corey-Chaykovsky cyclopropanation, cyclopropane fatty acids, mechanistic probes, fatty acid desaturation

Cyclopropane fatty acids, such as $(9 R, 10 S)$-dihydrosterculic acid (1) are a structurally unique class of fatty acids produced by a variety of organisms. ${ }^{1}$ The presence of their cyclopropane ring confers oxidative stability to lipidic ensembles relative to their olefinic counterparts while maintaining favourable biophysical properties, such as membrane fluidity, and greater tolerance of low $\mathrm{pH} .^{2}$ Interestingly, in some plant species, cis-cyclopropane fatty acids are thought to be converted into the corresponding cyclopropene compounds via a unique syn-dehydrogenation (desaturation) reaction. Such cyclopropene fatty acids are potent inhibitors of mammalian stearoyl CoA $\Delta^{9}$ desaturases (SCDs). Humans have two SCD homologues - SCD1 and SCD5. The X-ray structure of both human ${ }^{3}$ and murine ${ }^{4}$ variants of SCD1 were recently published. Mice deficient in SCD1 demonstrated improved insulin sensitivity and lipid metabolic profiles when fed a high-fat diet ${ }^{5,6}$ and dysregulation of SCD1 in humans has implications in diabetes, ${ }^{7}$ metabolic syndrome, ${ }^{8}$ and cancer ${ }^{9}{ }^{2}$ therefore, SCD1 is an active therapeutic target. ${ }^{10}$ The proposed mechanism for cis-cyclopropane to cyclopropene bioconversion involves stepwise hydrogen removal in a manner similar to that established for the desaturase-mediated dehydrogenation of cisolefinic fatty acids to give acetylenic products; ${ }^{11}$ however, further details, including the cryptoregiochemistry of this process (i.e., which hydrogen is removed first), have not been elucidated. The situation is complicated by the fact that the putative cyclopropane fatty acid desaturases have not been isolated or characterised. Nevertheless, as part of our ongoing interest in fatty acid desaturation ${ }^{12}$ and cyclopropane fatty acids ${ }^{13-15}$ we have undertaken a mechanistic study of the biochemical desaturation of $\mathbf{1}$ to $\mathbf{2}$ (Figure 1 ). Herein, we report the asymmetric synthesis of deuteriumlabelled dihydrosterculic acids appropriate for use in evaluating the individual primary kinetic isotope effects on $\mathrm{C}-\mathrm{H}$ bond cleavage at C9 and C10.

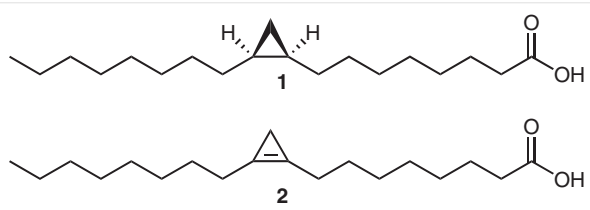

Figure 1 Structures $(9 R, 10 S)$-dihydrosterculic acid (1) and sterculic acid (2)

Our synthetic plan for the asymmetric synthesis of deuterium-labelled dihydrosterculic acids $\mathbf{3}$ and $\mathbf{4}$ involved preparation of cyclopropyl bis(sulfoxides) $\mathbf{5}$ and $\mathbf{6}$ via a diastereoselective cyclopropanation of $\alpha, \beta$-unsaturated chiral bis(sulfoxide) (7/8) derived from readily accessible $\left(S_{S}, S_{S}\right)$ 1,1-bis( $p$-toluenesulfinyl)methane $\mathbf{9}$, followed by regio- 
selective lithium-sulfoxide exchange and alkylation. ${ }^{16}$ Quenching with a proton or deuteron source would follow a second lithium-sulfoxide exchange (Scheme 1). ${ }^{14,17}$

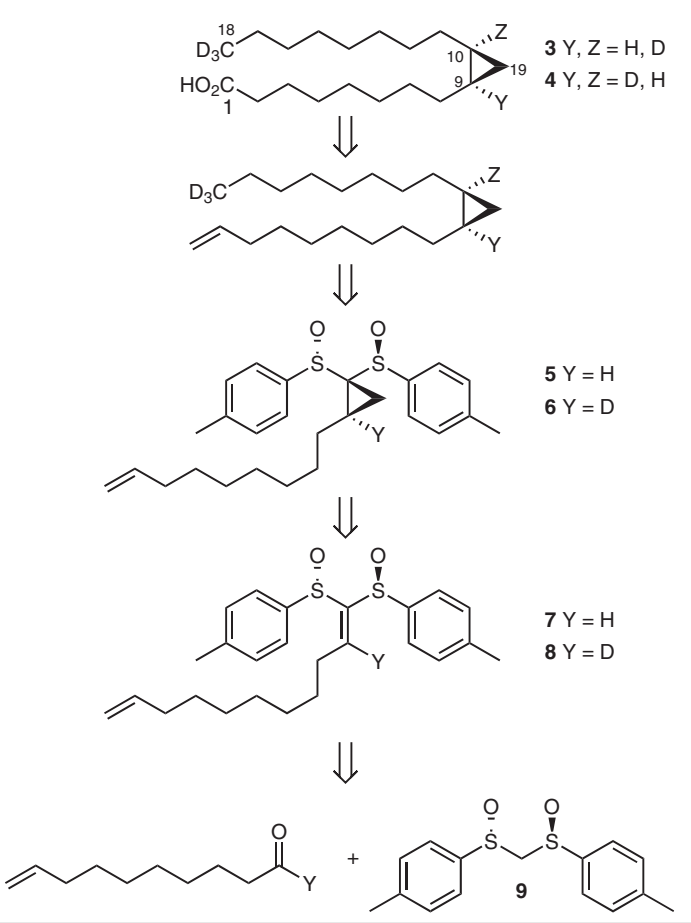

Scheme 1 Retrosynthesis of isotopically labelled dihydrosterculic acids 3 and 4

Synthesis of our 9-deuterio isotopologue 4 required dec-9-enal-1-d (11), which was prepared from dec-9-en-1ol (Scheme 2). Jones oxidation and Fischer esterification were followed by reduction with lithium aluminium deuteride (LAD) to afford dec-9-en-1-ol-1,1- $d_{2}$ (10), which was transformed into the requisite aldehyde $\mathbf{1 1}$ via Swern oxidation.

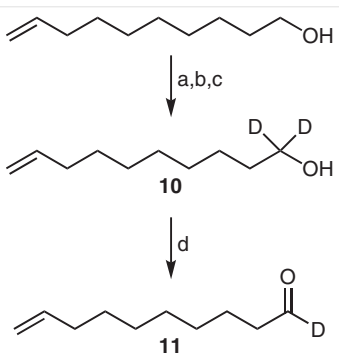

Scheme 2 Reagents and conditions: (a) $\mathrm{CrO}_{3}$, aq $\mathrm{H}_{2} \mathrm{SO}_{4}$, acetone, $0{ }^{\circ} \mathrm{C} \rightarrow$ r.t., 20 h, 95\%; (b) $\mathrm{H}_{2} \mathrm{SO}_{4}$ (cat.), IPA, $\Delta, 18$ h, $90 \%$; (c) LAD, THF, r.t., 1 h, $96 \%$; (d) $[\mathrm{ClC}(\mathrm{O})]_{2}$, DMSO, TEA, $\mathrm{CH}_{2} \mathrm{Cl}_{2},-78^{\circ} \mathrm{C}, 1$ h, $81 \%$.

Addition of the anion of $\mathbf{9}$ to $\mathbf{1 1}$ afforded the desired alcohol $\mathbf{1 2}$ as a mixture of alcohol epimers and a minor amount of alkene 13 (Scheme 3). Excess aldehyde was re- moved from the crude reaction mixture by rapid filtration through a silica plug, as the unlabelled isotopologue of $\mathbf{1 3}$ was known to undergo Mislow-Evans rearrangement upon prolonged exposure to silica gel. ${ }^{14,18,19}$ The resultant mixture of 12 and 13 was exposed to a water-soluble carbodiimide to complete the conversion into 13 , which was again passed through a silica plug and immediately exposed to Corey-Chaykovsky cyclopropanation conditions. This produced two cyclopropane diastereomers in an 85:15 ratio, with the major product being the desired diastereomer 6, which was isolated in $43 \%$ yield over three steps, with the final step requiring iterative chromatography to remove the minor diastereomer completely.

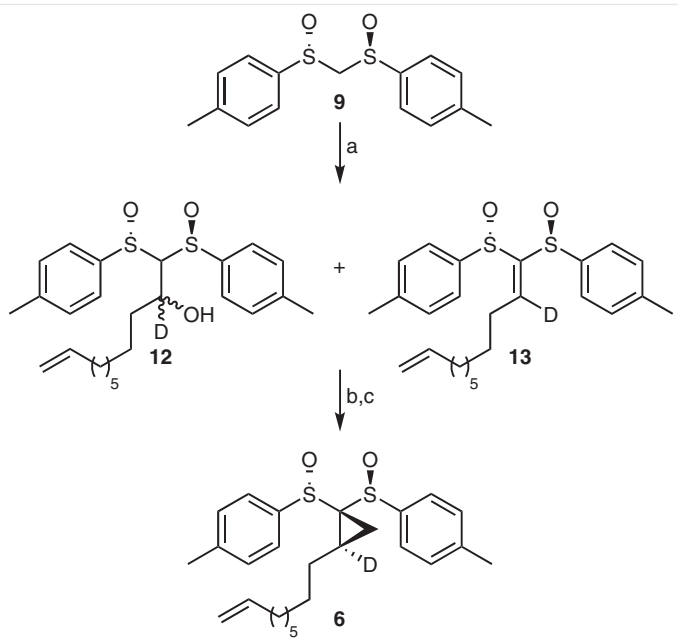

Scheme 3 Reagents and conditions: (a) n-BuLi, THF, $-50{ }^{\circ} \mathrm{C}$ to $-40{ }^{\circ} \mathrm{C}, 1$ h; $-78^{\circ} \mathrm{C}, 15 \mathrm{~min} ; \mathbf{1 1},-78^{\circ} \mathrm{C}, 30 \mathrm{~min}$; (b) $\mathrm{CuCl}_{2}$ (cat.), $\mathrm{N}$-cyclohexyl- $\mathrm{N}^{\prime}$ (2-morpholinoethyl)carbodiimide metho-p-toluenesulfonate, MeCN, r.t., $12 \mathrm{~h}$; (c) $\mathrm{Me}_{3} \mathrm{~S}(\mathrm{O}) \mathrm{l}, \mathrm{NaH}$, DMSO, r.t., 13 h, $43 \%$ over three steps (major diastereomer).

As we intend to employ mass spectrometry to analyse the results of our competitive kinetic isotope studies, we required a mass tag to differentiate products derived from D-labelled isotopologues and unlabelled dihydrosterculic acid. Accordingly, we prepared 1 -iodooctane-8,8,8- $d_{3}(\mathbf{1 5})^{20}$ from 1,8-octanediol (Scheme 4). Monobenzylation was followed by oxidation to the corresponding aldehyde. Szpliman's protocol for 2,2,6,6-tetramethylpiperidine-1-oxyl (TEMPO)-catalysed oxidation to the mixed anhydride and conversion into the isopropyl ester ${ }^{21}$ then provided facile access to ester 14. Subsequent reduction with LAD, alcohol tosylation, ${ }^{22}$ and tosylate reduction with LAD afforded the desired terminal $\mathrm{CD}_{3}$ group. Hydrogenolysis with Pearlman's catalyst, followed by Appel iodination produced the desired iodide $\mathbf{1 5}$ in high yield. 


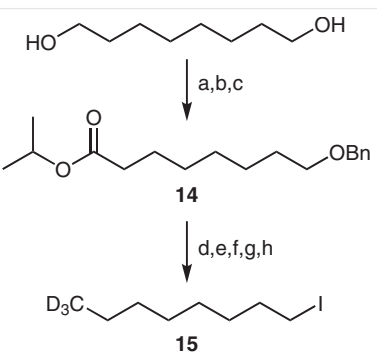

Scheme 4 Reagents and conditions: (a) $\mathrm{NaH}, \mathrm{BnBr}$, THF/DMF, $0{ }^{\circ} \mathrm{C}$ to r.t., 18 h, 51\%; (b) TEMPO (1 mol\%), $\mathrm{KBr}(10 \mathrm{~mol} \%), \mathrm{NaOCl}, \mathrm{CH}_{2} \mathrm{Cl}_{2}, \mathrm{pH} 8.6$ buffer, $0{ }^{\circ} \mathrm{C}, 0.5 \mathrm{~h}, 99 \%$; (c) TEMPO ( 5 mol\%), pivalic acid, $t$ - $\mathrm{BuOCl}$, pyr., $\mathrm{MeCN}, 0^{\circ} \mathrm{C}$, then IPA, DIPEA, DMAP, r.t., $18 \mathrm{~h}, 91 \%$; (d) LAD, THF, $0{ }^{\circ} \mathrm{C}$ to r.t., $6 \mathrm{~h}, 84 \%$; (e) TsCl, TEA, $\mathrm{Me}_{3} \mathrm{~N} \cdot \mathrm{HCl}(10 \mathrm{~mol} \%)$, toluene, $0{ }^{\circ} \mathrm{C}, 1 \mathrm{~h}, 89 \%$; (f) LAD, THF, $0{ }^{\circ} \mathrm{C}$ to r.t., 2.5 h, $77 \%$; (g) $\mathrm{H}_{2}\left(1 \mathrm{~atm}\right.$.), cat. $\mathrm{Pd}(\mathrm{OH})_{2} / \mathrm{C}$, EtOAc, r.t., 48 h, $98 \%$; (h) $\mathrm{Ph}_{3} \mathrm{P}, \mathrm{I}_{2}$, imidazole, $\mathrm{CH}_{2} \mathrm{Cl}_{2}, 0{ }^{\circ} \mathrm{C}$ to r.t., $0.5 \mathrm{~h}, 96 \%$.

With 15 in hand, we proceeded with the lithium-sulfoxide exchange/alkylation reaction (Scheme 5). Interestingly, the addition of $n$-BuLi to $\mathbf{6}$ led to contra-steric cleavage of the more hindered sulfoxide; ${ }^{16,17}$ subsequent addition of 5 equivalents of iodide $\mathbf{1 5}$ afforded the desired dialkylcyclopropane sulfoxide $\mathbf{1 6}$ in moderate yield. Addition of $t$-BuLi and quenching with $\mathrm{MeOH}$ produced the desired cis-cyclopropane 17.

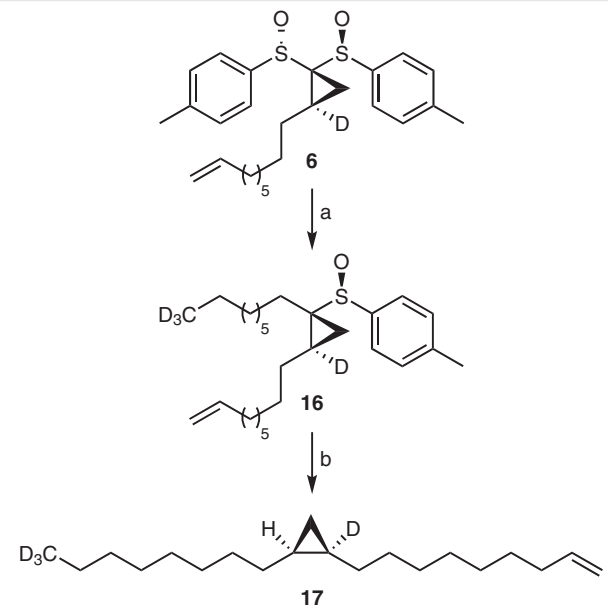

Scheme 5 Reagents and conditions: (a) n-BuLi, THF, $-78^{\circ} \mathrm{C}$ to $-40{ }^{\circ} \mathrm{C}, 1$ h; $15,-78^{\circ} \mathrm{C}, 3 \mathrm{~h}, 54 \%$; (b) $t$-BuLi, toluene, $-78^{\circ} \mathrm{C}, 1 \mathrm{~min}$; $\mathrm{MeOH},-$ $78{ }^{\circ} \mathrm{C}$ to $0{ }^{\circ} \mathrm{C}, 1 \mathrm{~h}, 70 \%$.

Our 10-deuteriodihydrosterculic acid isotopologue 3 was envisaged to accede from $\mathbf{5}$ - the variant of $\mathbf{6}$ lacking the deuterium on the cyclopropane ring. Cyclopropane bis(sulfoxide) $\mathbf{5}$ was prepared from $\mathbf{9}$ and 9-decenal in 35\% isolated yield over three steps, with the cyclopropanation step producing an 86:14 ratio of diastereomers, which were separated by analogy to $6 .^{14,18}$
The lithium-sulfoxide exchange/alkylation of 5 proceeded in the expected moderate yield (Scheme 6). The subsequent lithium-sulfoxide exchange/deuteration of 18 afforded some surprising results. Unlike the lithium-sulfoxide exchange reaction of $\mathbf{5}$, the reaction of $\mathbf{1 8}$ with $t$-BuLi produces an intermediate cyclopropyllithium species 19 that lacks the stabilisation afforded by a residual sulfoxide group. ${ }^{23}$ Accordingly, the more reactive $t$-BuLi was used and t-butyl $p$-tolyl sulfoxide (20) was formed as a byproduct. This sulfoxide lacks acidic protons on the $\alpha$ carbon; nevertheless, when 18 was allowed to stir for 10 minutes at $-78{ }^{\circ} \mathrm{C}$ after a slow addition of $t$-BuLi followed by the addition of a large excess of MeOD, we observed less than $5 \% \mathrm{D}$ incorporation on the cyclopropane ring. We hypothesise that even at $-78{ }^{\circ} \mathrm{C}$, cyclopropyllithium 19 rapidly deprotonates 20, most likely via directed orthometallation, ${ }^{24}$ though remote deprotonation of the methyl group of the tolyl residue, or E2 elimination via deprotonation of the $t$ butyl group cannot be ruled out. Such a phenomenon may also explain the moderate yields obtained in transformations of substrates similar to 18. ${ }^{17}$ Thus, we surmised that a rapid addition of $t$-BuLi followed by immediate quenching would improve the deuterium labelling efficiency. This supposition proved to be correct, as we obtained a $90 \%$ yield of desired cyclopropane $\mathbf{2 1}$ with an 84\% D incorporation at C10.

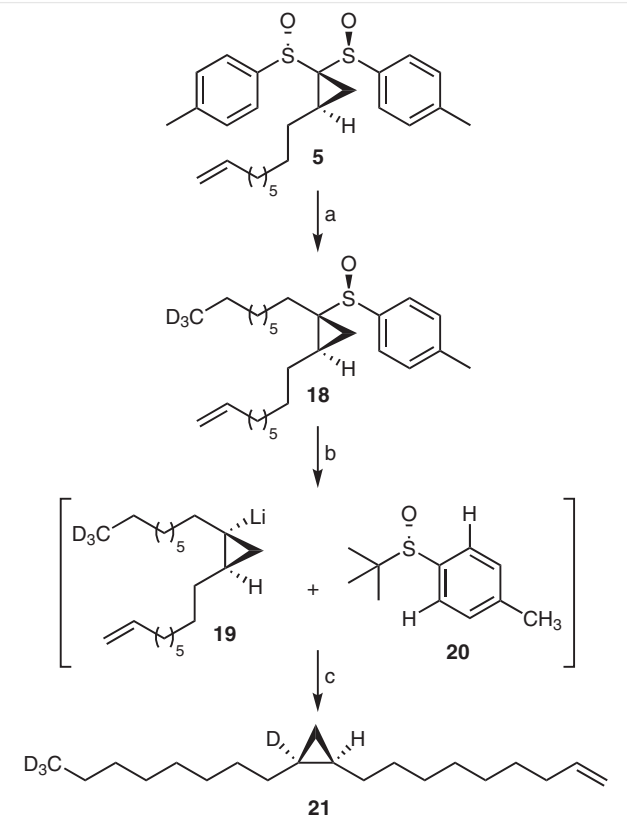

Scheme 6 Reagents and conditions: (a) n-BuLi, THF, $-78{ }^{\circ} \mathrm{C}$ to $-40{ }^{\circ} \mathrm{C}$, $1 \mathrm{~h} ; \mathbf{1 5},-78{ }^{\circ} \mathrm{C}, 3 \mathrm{~h}, 64 \%$; (b) $t$-BuLi, toluene, $-78^{\circ} \mathrm{C}, 10 \mathrm{~s}$; (c) MeOD, $-78{ }^{\circ} \mathrm{C}$ to $0{ }^{\circ} \mathrm{C}, 1 \mathrm{~h}, 90 \%$.

Having successfully prepared regioisomeric deuteriumlabelled cyclopropane alkenes 17 and 21, we completed the synthesis of $\mathbf{3}$ and $\mathbf{4}$ via Marshall ozonolysis and hydrolysis (Scheme 7). 


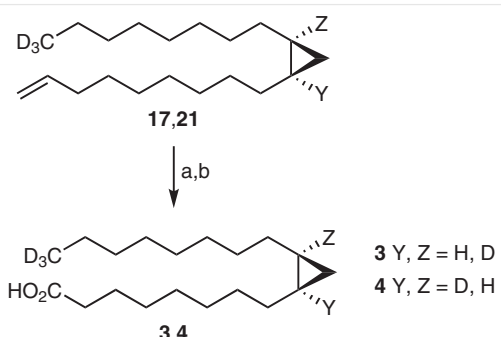

3,4

Scheme 7 Reagents and conditions: (a) $\mathrm{O}_{3}, \mathrm{NaOH}, \mathrm{MeOH}, \mathrm{CH}_{2} \mathrm{Cl}_{2}$, $-78{ }^{\circ} \mathrm{C}, 1.5 \mathrm{~h}$; (b) $\mathrm{LiOH} \cdot \mathrm{H}_{2} \mathrm{O}, \mathrm{MeOH}, \Delta, 15 \mathrm{~h}$; (3: $54 \%$ over two steps; 4 : $85 \%$ over two steps).

In conclusion, we have successfully synthesised isotopically labelled and mass-tagged isotopologues of dihydrosterculic acid for use in in vitro and in vivo studies of the cryptoregiochemistry of desaturation to form sterculic acid. Efforts to isolate and functionally express the putative desaturase gene are ongoing and results will be reported in due course.

All reagents were reagent grade and purchased from Sigma-Aldrich, Fluka, Analar, or Cambridge Isotope Laboratories Inc. and used as received, with the following exceptions: $\mathrm{PhMe}, \mathrm{CH}_{2} \mathrm{Cl}_{2}$, DMSO, DIPA and MeCN were distilled from $\mathrm{CaH}_{2} ; \mathrm{Et}_{2} \mathrm{O}$ and THF was distilled from $\mathrm{LiAlH}_{4}$ or sodium benzophenone ketyl; and all alkyl halides (commercial or prepared) were purified by elution through a short column of aluminium oxide (activated, basic, Brockman I) prior to use. Ozone was generated by using an A2Z Systems Inc. A2ZS-SGLAB ozone generator with a $0.5 \mathrm{~L} / \mathrm{min} \mathrm{O}_{2}$ flow. All reactions involving air- or moisture-sensitive reagents or intermediates were performed under an $\mathrm{Ar}$ or $\mathrm{N}_{2}$ atmosphere in glassware that was flame-dried or oven-dried. Reaction temperatures refer to the temperature of the cooling/heating bath. For the more unusual temperatures, a Neslab Cryotrol cryobath was used with a liquid coolant composed of a mixture of acetone and $\mathrm{MeOH}(1: 1)$. Volatile solvents were removed under reduced pressure using a Heidolph rotary evaporator at $40{ }^{\circ} \mathrm{C}$ (bath temperature). Thin-layer chromatography was performed on glass-backed Extra Hard Layer (60 Å) TLC plates purchased from Silicycle. Spots were visualised by fluorescence quenching under UV light $(254 \mathrm{~nm})$ and/or staining with aqueous ceric ammonium molybdate, iodine on silica gel, or $\mathrm{KMnO}_{4}$. Chromatography was performed using forced flow (flash chromatography, FCC) on Silia-P Flash silica gel (40-62 $\mu \mathrm{m})$ from Silicycle or adsorbed onto Celite 521 from Sigma-Aldrich and was performed using dry column vacuum chromatography (DCVC) ${ }^{25}$ with SiliaFlash E60 silica gel $(15-40 \mu \mathrm{m})$ from Silicycle. Compounds that were dried under high vacuum refer to a reduced pressure of $\mathrm{ca}$. 20 mTorr. FTIR spectra were recorded with a Varian 1000 Scimitar Series or an ABB Bomem MB Series spectrometer and were obtained as thin films on sodium chloride and are reported in wavenumbers $\left(\mathrm{cm}^{-}\right.$ $\left.{ }^{1}\right) .{ }^{1} \mathrm{H}$ and ${ }^{13} \mathrm{C}$ NMR spectra were recorded with a Bruker Avance 300 or Bruker Avance III 400 spectrometer at 300 or $400 \mathrm{MHz}$ for ${ }^{1} \mathrm{H}$ and 75 or $100 \mathrm{MHz}$ for ${ }^{13} \mathrm{C}$, respectively, and were obtained at the indicated field as solutions in $\mathrm{CDCl}_{3}$ (stored over activated $4 \AA$ molecular sieves) unless otherwise indicated. Chemical shifts are referenced to tetramethylsilane $(\delta=0.00 \mathrm{ppm})$ as an internal standard and are reported in parts per million (ppm, $\delta$ ) relative to TMS. Coupling con- stants $(J)$ are reported in $\mathrm{Hz}$, and the splitting abbreviations used are: s, singlet; d, doublet; t, triplet; q, quartet; $m$, multiplet. Chemical purity of compounds that were used without purification was determined by ${ }^{1} \mathrm{H}$ NMR spectroscopy. Yields refer to purified compounds unless explicitly indicated otherwise. Deuterium incorporation of deuterated compounds was determined by comparison of peak integrations of the labelled materials versus the integration of the same peak(s) in the ${ }^{1} \mathrm{H}$ NMR spectrum of the unlabeled compound.

\section{9-Decen-1,1-d -ol $\left.^{(10)}\right)^{26}$}

A solution of ester $\mathbf{S 2}(8.17 \mathrm{~g}, 38 \mathrm{mmol})$ in THF $(50 \mathrm{~mL})$ was added to a suspension of $\operatorname{LiAlD}_{4}(1.30 \mathrm{~g}, 31 \mathrm{mmol})$ in THF $(150 \mathrm{~mL})$ at $0{ }^{\circ} \mathrm{C}$ by using a cannula over $10 \mathrm{~min}$. The mixture was warmed to ambient temperature and stirred for $1 \mathrm{~h}$. The reaction mixture was re-cooled in an ice/water bath for 10 min before slowly quenching by portionwise addition of solid $\mathrm{Na}_{2} \mathrm{SO}_{4} \cdot 10 \mathrm{H}_{2} \mathrm{O}(10 \mathrm{~g})$. Acetone $(20 \mathrm{~mL})$ was added to ensure the consumption of any residual metal-deuteride species, and the sludgy mixture was vigorously stirred while warming to ambient temperature for $2 \mathrm{~h}$. The now white reaction mixture was filtered over Celite ${ }^{\circledR}$, washed with saturated aqueous Rochelle's salt $(2 \times 300$ $\mathrm{mL}$ ), dried over anhydrous $\mathrm{MgSO}_{4}$, filtered, and concentrated to give a light-yellow liquid (6.12 g). The crude liquid was purified by DCVC (2.5-10\%, EtOAc/hexanes) to afford the product.

Yield: $5.79 \mathrm{~g}(96 \%)$; clear liquid; $R_{f}=0.09$ ( $5 \%$, EtOAc/hexanes, $\mathrm{KMnO}_{4}$ ). FTIR ( $\mathrm{NaCl}$ plate): 3334, 2926, 2855, 1641, 1465, 1367, 1134, 967, $909 \mathrm{~cm}^{-1}$.

${ }^{1} \mathrm{H} \mathrm{NMR}\left(\mathrm{CDCl}_{3}, 300 \mathrm{MHz}\right): \delta=5.81\left(\mathrm{ddt},{ }^{3} J=17.1,10.2,6.6 \mathrm{~Hz}, 1 \mathrm{H}\right)$, 5.03-4.92 (m, 2 H), 2.04 (q, $\left.{ }^{3} \mathrm{~J}=7.5 \mathrm{~Hz}, 2 \mathrm{H}\right), 1.57-1.53$ (m, $\left.2 \mathrm{H}\right), 1.40-$ $1.23(\mathrm{~m}, 10 \mathrm{H}), 1.18(\mathrm{~s}, 1 \mathrm{H})$.

${ }^{13} \mathrm{C}$ NMR $\left(\mathrm{CDCl}_{3}, 75 \mathrm{MHz}\right): \delta=139.2,114.2,62.4\left(\mathrm{C} 1\right.$, quin, ${ }^{1} J_{\mathrm{CD}}=$ $21.0 \mathrm{~Hz}$, upfield $\alpha$-deuterium isotope $\left.\operatorname{shift}^{27}(0.1 \mathrm{ppm})\right), 33.8,32.6$, 29.4, 29.5, 29.1, 28.9, 25.7.

\section{Dec-9-en-1-d-al (11)}

A $-40{ }^{\circ} \mathrm{C}$ solution of DMSO $(6.6 \mathrm{~mL}, 93 \mathrm{mmol})$ in $\mathrm{CH}_{2} \mathrm{Cl}_{2}(30 \mathrm{~mL})$, was added to a solution of $(\mathrm{COCl})_{2}(3.9 \mathrm{~mL}, 46 \mathrm{mmol})$ in $\mathrm{CH}_{2} \mathrm{Cl}_{2}(260 \mathrm{~mL})$ at $-78{ }^{\circ} \mathrm{C}$ by using a cannula over $15 \mathrm{~min}$. The solution was stirred for 15 min. A $0{ }^{\circ} \mathrm{C}$ solution of $\mathbf{1 0}(5.1 \mathrm{~g}, 34 \mathrm{mmol})$ in $\mathrm{CH}_{2} \mathrm{Cl}_{2}(58 \mathrm{~mL})$ was then added by using a cannula over $15 \mathrm{~min}$ and the mixture was stirred for an additional $15 \mathrm{~min}$. $\mathrm{NEt}_{3}(24 \mathrm{~mL}, 174 \mathrm{mmol}$ ) was then added, and the reaction mixture was allowed to slowly warm to $0{ }^{\circ} \mathrm{C}$ over $4 \mathrm{~h}$. The reaction mixture was diluted in $\mathrm{H}_{2} \mathrm{O}(200 \mathrm{~mL})$. The organic layer was washed with $1 \mathrm{M}$ aqueous $\mathrm{HCl}(3 \times 150 \mathrm{~mL})$ then saturated aqueous $\mathrm{NaCl}(1150 \mathrm{~mL})$. The organic layer was dried over anhydrous $\mathrm{Na}_{2} \mathrm{SO}_{4}$, filtered then concentrated in vacuo to afford a yellow oil $(6.58 \mathrm{~g})$. The crude oil was purified by FCC $\left(5 \%, \mathrm{Et}_{2} \mathrm{O} /\right.$ hexanes $)$ to afford the product.

Yield: $4.38 \mathrm{~g}(81 \%, 99 \% \mathrm{D})$; clear liquid; $R_{f}=0.26\left(5 \%, \mathrm{Et}_{2} \mathrm{O} /\right.$ hexanes, $\mathrm{KMnO}_{4}$ ).

FTIR (NaCl plate): 3077, 2929, 2856, 2066, 1716, 1641, 1465, 1406, $1095,995,910 \mathrm{~cm}^{-1}$.

${ }^{1} \mathrm{H}$ NMR $\left(\mathrm{CDCl}_{3}, 300 \mathrm{MHz}\right): \delta=9.77\left(\mathrm{t},{ }^{3} \mathrm{~J}=1.8 \mathrm{~Hz}, 0.01 \mathrm{H}\right), 5.81$ (ddt, $\left.{ }^{3} \mathrm{~J}=17.1,10.2,6.6 \mathrm{~Hz}, 1 \mathrm{H}\right), 5.03-4.91(\mathrm{~m}, 2 \mathrm{H}), 2.42\left(\mathrm{t},{ }^{3} \mathrm{~J}=7.2 \mathrm{~Hz}\right.$, $2 \mathrm{H}$ ), $2.04\left(\mathrm{q},{ }^{3} \mathrm{~J}=7.2 \mathrm{~Hz}, 2 \mathrm{H}\right.$ ), 1.63 (quin, ${ }^{3} \mathrm{~J}=7.2 \mathrm{~Hz}, 2 \mathrm{H}$ ), 1.41-1.23 $(\mathrm{m}, 10 \mathrm{H})$.

${ }^{13} \mathrm{C} \operatorname{NMR}\left(\mathrm{C}_{6} \mathrm{D}_{6}, 100 \mathrm{MHz}\right): \delta=200.0\left(\mathrm{t},{ }^{1} \mathrm{~J}=26.0 \mathrm{~Hz}\right), 138.8,114.2,43.2$ $\left(\mathrm{t},{ }^{2} \mathrm{~J}=3.7 \mathrm{~Hz}\right), 33.8,29.1,28.9,28.8,28.7,21.8$. 


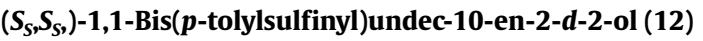

The protocol was adapted from the procedure reported by Malacria. ${ }^{28}$ A solution of $n$-BuLi in hexanes $(3.9 \mathrm{~mL}, 2.91 \mathrm{M}, 11.3 \mathrm{mmol}$ ) was added dropwise to a solution of bis(sulfoxide) $\mathbf{9}(2.99 \mathrm{~g}, 10.2 \mathrm{mmol})$ dissolved in THF $\left(43 \mathrm{~mL}\right.$ ) at $-50{ }^{\circ} \mathrm{C}$ (best results were obtained if bis(sulfoxide) was dried under vacuum at $65{ }^{\circ} \mathrm{C}$ for $18 \mathrm{~h}$ ). The light-yellow solution was allowed to warm to $-40^{\circ} \mathrm{C}$ for $1 \mathrm{~h}$ to ensure complete formation of the anion. The solution was then re-cooled to $-78{ }^{\circ} \mathrm{C}$ in an acetone/dry ice bath for $15 \mathrm{~min}$. Aldehyde 11 (6.51 g, $42 \mathrm{mmol}$ ) was chilled to $0{ }^{\circ} \mathrm{C}$ and added neat by using a cannula over $10 \mathrm{~min}$. The reaction was allowed to stir at this temperature for $30 \mathrm{~min}$ before quenching with saturated aqueous $\mathrm{NH}_{4} \mathrm{Cl}(60 \mathrm{~mL})$ and subsequent warming to ambient temperature. The layers were separated and the aqueous layer was extracted with $\mathrm{CH}_{2} \mathrm{Cl}_{2}(3 \times 50 \mathrm{~mL})$. The combined organic layers were washed with brine, dried over anhydrous $\mathrm{Na}_{2} \mathrm{SO}_{4}$, filtered and concentrated to give a yellow oil $(9.5 \mathrm{~g})$. This material was semi-purified by FCC (20-80\%, EtOAc/hexanes) to afford a mixture of diastereomeric alcohols 12 and dehydrated product 13.

Yield: $4.06 \mathrm{~g}$; pale-yellow oil; $R_{f}=0.42$ (50\%, EtOAc/hexanes, UV, $\mathrm{KMnO}_{4}$ ). The product was not fully characterised because of its limited shelf-life and complexity of spectra.

\section{$\left(\boldsymbol{S}_{S}, \boldsymbol{S}_{S}\right)$-1,1-Bis( $p$-tolylsulfinyl)-2-d-oct-1,10-diene (13)}

This protocol was adapted from the procedure reported by Malacria. ${ }^{28}$ A $500 \mathrm{~mL}$ round-bottomed flask was charged with the mixture of diastereomeric alcohols $\mathbf{1 2}$ and diene $\mathbf{1 3}$ prepared above (4.06 g, 9.10 $\mathrm{mmol}), \mathrm{MeCN}(180 \mathrm{~mL})$, and morpho-CDI (5.80 g, $13.7 \mathrm{mmol})$. To this solution, anhydrous $\mathrm{CuCl}_{2}$ (193 $\mathrm{mg}, 1.43 \mathrm{mmol}$ ) was added and the mixture was stirred at r.t. for 12 hours. The reaction mixture was diluted in $\mathrm{CH}_{2} \mathrm{Cl}_{2}(160 \mathrm{~mL})$ and filtered through a short pad of Celite ${ }^{\circledR}$ and silica gel; the filter cake was washed with $\mathrm{CH}_{2} \mathrm{Cl}_{2}(200 \mathrm{~mL})$ then EtOAc $(100 \mathrm{~mL})$ and concentrated in vacuo to afford 13 as a yellow to blue-green oil ( $3.72 \mathrm{~g})$. This oil was used without further purification because it was unstable to flash chromatography. $R_{f}=0.56(40 \%$, EtOAc, UV, $\mathrm{KMnO}_{4}$ ).

\section{$\left(S_{S}, S_{S}, 2 R\right)$-1,1-Bis(p-tolylsulfinyl)-2-d-2-dec-10-enylcyclopropane} (6)

DMSO (68 mL) was cautiously added to a mixture of $\mathrm{NaH}(1.04 \mathrm{~g}, 95 \%$, $41.2 \mathrm{mmol})$ and $\mathrm{Me}_{3} \mathrm{SOI}(9.55 \mathrm{~g}, 43.4 \mathrm{mmol})$ while stirring at r.t. until the mixture became homogeneous (30 $\mathrm{min})$. To this solution was added alkylidene bis-sulfoxide $\mathbf{1 3}(3.72 \mathrm{~g}, 8.66 \mathrm{mmol})$ and the resultant mixture was stirred at r.t. for $12 \mathrm{~h}$, at which point the reaction was quenched with saturated aqueous $\mathrm{NH}_{4} \mathrm{Cl}(100 \mathrm{~mL})$. The mixture was extracted with $\mathrm{Et}_{2} \mathrm{O}(3 \times 125 \mathrm{~mL})$ and the combined organic layers were washed with brine $(200 \mathrm{~mL})$, dried over anhydrous $\mathrm{Na}_{2} \mathrm{SO}_{4}$, filtered and concentrated to give a viscous yellow oil (3.38 g). The crude oil was exhaustively purified by FCC (toluene/Hexane/EtOAc/3methyl-2-butanone, 26:10:3:4) to afford 6.

Yield: $1.97 \mathrm{~g}$ (43\% over three steps); colourless oil; $R_{f}=0.14(20 \%$, EtOAc/toluene, UV, $\left.\mathrm{KMnO}_{4}\right) ;[\alpha]_{\mathrm{D}}^{26}=-114.08\left(c=0.233, \mathrm{CHCl}_{3}\right)$.

FTIR (NaCl plate): 3058, 2976, 2926, 2855, 1640, 1596, 1492, 1454, 1399, 1303, 1209, 1178, 1085, 1048, 1015, 994, 909, 809, 731, $635 \mathrm{~cm}^{-1}$.

${ }^{1} \mathrm{H}$ NMR $\left(\mathrm{CDCl}_{3}, 300 \mathrm{MHz}\right): \delta=7.57\left(\mathrm{~d},{ }^{3} \mathrm{~J}=8.1 \mathrm{~Hz}, 2 \mathrm{H}\right), 7.36\left(\mathrm{~d},{ }^{3} \mathrm{~J}=\right.$ $7.8 \mathrm{~Hz}, 2 \mathrm{H}), 7.21\left(\mathrm{~d},{ }^{3} \mathrm{~J}=6.6 \mathrm{~Hz}, 2 \mathrm{H}\right), 7.05\left(\mathrm{~d},{ }^{3} \mathrm{~J}=8.4 \mathrm{~Hz}, 2 \mathrm{H}\right), 5.81$ (ddt, ${ }^{3} \mathrm{~J}=17.1,10.2,6.6 \mathrm{~Hz}, 1 \mathrm{H}$ ), 5.03-4.92 (m, $2 \mathrm{H}$ ), 2.45 (s, $3 \mathrm{H}$ ), 2.39 (s, $3 \mathrm{H}), 2.04\left(\mathrm{q},{ }^{3} J=7.5 \mathrm{~Hz}, 2 \mathrm{H}\right), 1.78-1.68(\mathrm{~m}, 2 \mathrm{H}), 1.41-1.19(\mathrm{~m}$, $10 \mathrm{H})$.
${ }^{13} \mathrm{C}$ NMR $\left(\mathrm{CDCl}_{3}, 75 \mathrm{MHz}\right): \delta=143.1,142.2,139.1,138.9,138.4,130.1$, $129.8,126.5,125.2,114.2,62.9,33.8,29.6,29.3,29.0,29.0,28.9,27.3$ (C3, upfield $\beta$-deuterium isotope shift $\left.{ }^{14,18}(0.09 \mathrm{ppm})\right), 24.7\left(\mathrm{C} 2, \mathrm{t},{ }^{1} J_{\mathrm{CD}}\right.$ $=23.0 \mathrm{~Hz}$, upfield $\alpha$-deuterium isotope $\left.\operatorname{shift}^{14,18}(0.3 \mathrm{ppm})\right), 21.6$, $21.5,13.3$

\section{Isopropyl 8-(Benzyloxy)octanoate (14)}

This procedure was adapted from the work of Szpilman et al. ${ }^{21}$ Aldehyde S4 (6.18 g, $26.4 \mathrm{mmol})$, pivalic acid (3.0 g, $29.4 \mathrm{mmol})$, TEMPO (207 mg, $1.3 \mathrm{mmol})$, and pyridine $(4.3 \mathrm{~mL}, 53.2 \mathrm{mmol}$ ) were dissolved in $\mathrm{MeCN}(66 \mathrm{~mL})$ and cooled to $0{ }^{\circ} \mathrm{C}$ and flushed with Argon. ${ }^{\mathrm{t}} \mathrm{BuOCl}$ $(3.22 \mathrm{~g}, 29.7 \mathrm{mmol}$ ) was then added dropwise over $10 \mathrm{~min}$. The solution was allowed to warm to ambient temperature over $15 \mathrm{~min}$, and DIPA (10.1 mL, $58.0 \mathrm{mmol})$, isopropanol (3.6 mL, $47 \mathrm{mmol}$ ) and $\operatorname{DMAP}(0.32 \mathrm{~g}, 2.6 \mathrm{mmol})$ were added sequentially. The reaction was stirred overnight $(18 \mathrm{~h})$ at r.t. The reaction was diluted with saturated aqueous $\mathrm{NaHCO}_{3}(1.3 \mathrm{~L})$, extracted with EtOAc $(3 \times 250 \mathrm{~mL})$ and the organic layers were combined, washed with brine, dried over anhydrous $\mathrm{Na}_{2} \mathrm{SO}_{4}$, filtered and concentrated to yield a crude pale-pink oil ( $7.67 \mathrm{~g})$. The crude oil was purified by FCC (20-30\%, EtOAc/hexanes) to give 14

Yield: $7.04 \mathrm{~g}$ (91\%); colourless liquid; $R_{f}=0.77$ (30\%, EtOAc/hexanes; UV).

FTIR ( $\mathrm{NaCl}$ plate): 3064, 3031, 2979, 2934, 2857, 1950, 1730, 1466, 1373, 1309, 1253, 1202, 1179, 1109, 1028, 963, 901, 823, $736 \mathrm{~cm}^{-1}$.

${ }^{1} \mathrm{H}$ NMR $\left(\mathrm{CDCl}_{3}, 300 \mathrm{MHz}\right): \delta=7.35-7.16(\mathrm{~m}, 5 \mathrm{H}), 5.00\left(\mathrm{sep},{ }^{3} \mathrm{~J}=\right.$ $6.3 \mathrm{~Hz}, 1 \mathrm{H}), 4.50(\mathrm{~s}, 2 \mathrm{H}), 3.46\left(\mathrm{t},{ }^{3} \mathrm{~J}=6.6 \mathrm{~Hz}, 2 \mathrm{H}\right), 2.25\left(\mathrm{t},{ }^{3} \mathrm{~J}=7.5 \mathrm{~Hz}\right.$, $2 \mathrm{H}), 1.66-1.56$ (m, $4 \mathrm{H}), 1.45-1.25(\mathrm{~m}, 6 \mathrm{H}), 1.22\left(\mathrm{~d},{ }^{3} \mathrm{~J}=6.3 \mathrm{~Hz}, 6 \mathrm{H}\right)$.

${ }^{13} \mathrm{C} \mathrm{NMR}\left(\mathrm{CDCl}_{3}, 75 \mathrm{MHz}\right): \delta=173.3,138.8,128.4,127.6,127.6,127.5$, 72.9, 70.4, 67.3, 34.7, 29.8, 29.2, 29.1, 26.1, 25.0, 21.9.

\section{1-Iodo-8,8,8- $\boldsymbol{d}_{\mathbf{3}}$-octane $(\mathbf{1 5})^{20}$}

Alcohol S8 (0.61 g, $4.6 \mathrm{mmol}), \mathrm{PPh}_{3}(1.55 \mathrm{~g}, 5.9 \mathrm{mmol})$, imidazole (0.41 g, $5.9 \mathrm{mmol}$ ) were dissolved in $\mathrm{CH}_{2} \mathrm{Cl}_{2}(7.5 \mathrm{~mL})$ at ambient temperature, before cooling to $0{ }^{\circ} \mathrm{C}$. $\mathrm{I}_{2}(1.57 \mathrm{~g}, 5.9 \mathrm{mmol})$ was added slowly and a vigorous gas evolution was observed. The orange reaction mixture was warmed to ambient temperature and stirred for $30 \mathrm{~min}$. After the reaction was judged to be complete by TLC, saturated aqueous $\mathrm{Na}_{2} \mathrm{~S}_{2} \mathrm{O}_{3}(10 \mathrm{~mL})$ was added, and the mixture was stirred for 5 $\mathrm{min}$. The layers were separated and aqueous layer was extracted with $\mathrm{CH}_{2} \mathrm{Cl}_{2}(3 \times 10 \mathrm{~mL})$. Organic layers were combined, dried over anhydrous $\mathrm{MgSO}_{4}$, and filtered over a short pad of silica. After thorough washing of the filter cake with hexanes $(30 \mathrm{~mL})$, the solution was concentrated to give a slushy white solid. This solid was suspended in hexanes $(10 \mathrm{~mL})$ and cooled to $0{ }^{\circ} \mathrm{C}$ without stirring. The suspension was filtered over a short pad of silica, and the filter cake was washed with cold hexanes $(50 \mathrm{~mL})$, the filtrate was concentrated to give the product.

Yield: $1.07 \mathrm{~g}$ (96\%); colourless liquid; $R_{f}=0.74$ (100\%, hexanes; UV, $\mathrm{KMnO}_{4}$ ).

FTIR (NaCl plate): 2923, 2854, 2212, 2121, 2075, 1463, 1196, 1165 , $1055,720 \mathrm{~cm}^{-1}$.

${ }^{1} \mathrm{H} \mathrm{NMR}\left(\mathrm{CDCl}_{3}, 400 \mathrm{MHz}\right): \delta=3.19\left(\mathrm{t},{ }^{3} \mathrm{~J}=6.8 \mathrm{~Hz}, 2 \mathrm{H}\right), 1.82$ (quin, ${ }^{3} \mathrm{~J}=$ $7.2 \mathrm{~Hz}, 2 \mathrm{H}), 1.45-1.35$ (m, $2 \mathrm{H}), 1.35-1.14(\mathrm{~m}, 8 \mathrm{H})$.

${ }^{13} \mathrm{C} \mathrm{NMR}\left(\mathrm{CDCl}_{3}, 100 \mathrm{MHz}\right): \delta=33.6,31.7,30.5,29.1,28.5,22.3(\mathrm{C} 7$, upfield $\beta$-deuterium isotope shift $\left.{ }^{29}(0.2 \mathrm{ppm})\right), 13.2\left(\mathrm{C} 8\right.$, quin, ${ }^{1} J_{\mathrm{CD}}=$ $19.0 \mathrm{~Hz}$, upfield $\alpha$-deuterium isotope $\left.\operatorname{shift}^{29}(0.9 \mathrm{ppm})\right), 7.21$. 


\section{$\left(S_{S}\right)$-1-p-Tolylsulfinyl-(1R,2R)-2-d-2-(non-8-en-1-yl)-1-(8,8,8- $d_{3}-$ octyl)cyclopropane (16)}

This protocol was adapted from the procedure reported by Marek and co-workers. ${ }^{17}$ A solution of $n$-BuLi in hexanes $(2.15 \mathrm{~mL}, 2.50 \mathrm{M}, 4.7$ mmol) was added dropwise to a solution of bis(sulfoxide) $6(0.92 \mathrm{~g}$, $2.1 \mathrm{mmol})$ in THF $(21 \mathrm{~mL})$ at $-78{ }^{\circ} \mathrm{C}$. The solution was then warmed to $-40{ }^{\circ} \mathrm{C}$ and stirred for $1 \mathrm{~h}$. Labelled iodooctane $\mathbf{1 5}$ (3.01 g, $12.4 \mathrm{mmol}$ ) was added to the reaction mixture dropwise neat by using a cannula and stirred at $0{ }^{\circ} \mathrm{C}$ for $3 \mathrm{~h}$. The reaction was quenched with saturated aqueous $\mathrm{NH}_{4} \mathrm{Cl}(30 \mathrm{~mL})$; the layers were separated and the aqueous layer was extracted with $\mathrm{Et}_{2} \mathrm{O}(3 \times 30 \mathrm{~mL})$. The combined organic layers were combined and dried over anhydrous $\mathrm{Na}_{2} \mathrm{SO}_{4}$, filtered and concentrated to give a pale-yellow liquid $(3.45 \mathrm{~g})$. The crude oil was purified by FCC (10-30\%, $\mathrm{Et}_{2} \mathrm{O}$ in hexanes) to afford 16.

Yield: $0.48 \mathrm{~g}(60 \%)$; colourless oil; $R_{\mathrm{f}}=0.29$ (30\%, $\mathrm{Et}_{2} \mathrm{O} /$ hexanes, UV, $\left.\mathrm{KMnO}_{4}\right) ;[\alpha]_{\mathrm{D}}^{25}=+62.13\left(c=0.235, \mathrm{CHCl}_{3}\right)$.

FTIR ( $\mathrm{NaCl}$ plate): 3075, 2925, 2855, 1640, 1463, 1085, 1053, 908 , $807,722 \mathrm{~cm}^{-1}$.

${ }^{1} \mathrm{H}$ NMR $\left(\mathrm{CDCl}_{3}, 300 \mathrm{MHz}\right): \delta=7.50\left(\mathrm{~d},{ }^{3} \mathrm{~J}=8.1 \mathrm{~Hz}, 2 \mathrm{H}\right), 7.29\left(\mathrm{~d},{ }^{3} \mathrm{~J}=\right.$ $7.8 \mathrm{~Hz}, 2 \mathrm{H}), 5.81$ (ddt, $\left.{ }^{3} J=17.1,10.2,6.6 \mathrm{~Hz}, 1 \mathrm{H}\right), 5.03-4.91(\mathrm{~m}, 2 \mathrm{H})$, $2.41(\mathrm{~s}, 3 \mathrm{H}), 2.03\left(\mathrm{q},{ }^{3} \mathrm{~J}=7.5 \mathrm{~Hz}, 2 \mathrm{H}\right), 1.65-1.45(\mathrm{~m}, 2 \mathrm{H}), 1.44-1.05$ $(\mathrm{m}, 25 \mathrm{H}), 0.42\left(\mathrm{~d},{ }^{2} J=5.4 \mathrm{~Hz}, 1 \mathrm{H}\right)$.

${ }^{13} \mathrm{C} \mathrm{NMR}\left(\mathrm{CDCl}_{3}, 75 \mathrm{MHz}\right): \delta=141.4,140.0,139.2,129.5,125.1,114.2$, 44.2, 33.8, 31.8, 29.7, 29.4, 29.4, 29.3, 29.5, 29.2, 29.0, 28.9, 28.2, 27.4, $26.1,22.4,21.4,18.5\left(\mathrm{C} 2, \mathrm{t},{ }^{1} J_{\mathrm{CD}}=25.0 \mathrm{~Hz}\right.$, upfield $\alpha$-deuterium isotope shift $\left.{ }^{14,18}(0.3 \mathrm{ppm})\right), 14.6,13.2\left(\mathrm{C} 8\right.$, quin, ${ }^{1} J_{\mathrm{CD}}=19.0 \mathrm{~Hz}$, upfield $\alpha$ deuterium isotope $\left.\operatorname{shift}^{14,18}(0.9 \mathrm{ppm})\right)$.

(1R,2S)-1-d-1-(Non-8-en-1-yl)-2-(8,8,8-d d $_{\mathbf{3}}$-octyl)cyclopropane (17) A $t$-BuLi solution in pentane $(2.15 \mathrm{~mL}, 1.5 \mathrm{M}, 3.2 \mathrm{mmol})$ was added in one portion (as quickly and safely as possible) to a stirred solution of sulfoxide 15 ( $438 \mathrm{mg}, 1.0 \mathrm{mmol}$ ) in toluene $\left(21 \mathrm{~mL}\right.$ ) at $-78{ }^{\circ} \mathrm{C}$. The reaction was stirred for $1 \mathrm{~min}$ before quenching with $\mathrm{MeOH}(3 \mathrm{~mL})$ and allowing it to warm to $0{ }^{\circ} \mathrm{C}$ for $1 \mathrm{~h}$. Saturated $\mathrm{NH}_{4} \mathrm{Cl}(25 \mathrm{~mL})$ was then added, the layers were separated and the aqueous layer was extracted with $\mathrm{Et}_{2} \mathrm{O}(3 \times 20 \mathrm{~mL})$. The combined organic layers were dried over anhydrous $\mathrm{MgSO}_{4}$, filtered, and concentrated to afford a crude oil $(0.65 \mathrm{~g})$. The oil was the purified by FCC (100\%, HPLC grade hexanes) to afford 16.

Yield: $202 \mathrm{mg}$ (70\%); colourless oil; $R_{f}=0.88\left(100 \%\right.$, hexanes, $\mathrm{I}_{2}$, $\left.\mathrm{KMnO}_{4}\right) ;[\alpha]_{\mathrm{D}}^{25}=+2.012\left(c=0.400, \mathrm{CHCl}_{3}\right)$.

FTIR (NaCl plate): 3060, 2989, 2925, 2854, 1641, 1465, $909 \mathrm{~cm}^{-1}$.

${ }^{1} \mathrm{H} \mathrm{NMR}\left(\mathrm{CDCl}_{3}, 300 \mathrm{MHz}\right): \delta=5.82\left(\mathrm{ddt},{ }^{3} J=17.1,10.2,6.6 \mathrm{~Hz}, 1 \mathrm{H}\right)$, 5.05-4.89 (m, $2 \mathrm{H}), 2.04$ (q, $\left.{ }^{3} \mathrm{~J}=7.2 \mathrm{~Hz}, 2 \mathrm{H}\right), 1.45-1.22(\mathrm{~m}, 26 \mathrm{H})$, $0.71-0.58(\mathrm{~m}, 1 \mathrm{H}), 0.58-0.51(\mathrm{~m}, 1 \mathrm{H}),-0.34(\mathrm{t}, J=4.8 \mathrm{~Hz}, 1 \mathrm{H})$.

${ }^{13} \mathrm{C}$ NMR $\left(\mathrm{CDCl}_{3}, 75 \mathrm{MHz}\right): \delta=139.2,114.1,33.8,31.9,30.2,30.2,29.7$, 29.6, 29.6, 29.4, 29.2, 29.0, 28.7, 28.6, 22.4, 15.7 (C2, upfield $\beta$-deuterium isotope shift $\left.{ }^{14,18}(0.1 \mathrm{ppm})\right), 15.4\left(\mathrm{C} 1, \mathrm{t},{ }^{1} J_{\mathrm{CD}}=23.0 \mathrm{~Hz}\right.$, upfield $\alpha$ deuterium isotope $\left.\operatorname{shift}^{14,18}(0.3 \mathrm{ppm})\right), 13.2\left(\mathrm{C} 8\right.$, quin, ${ }^{1} J_{\mathrm{CD}}=19.0 \mathrm{~Hz}$, upfield $\alpha$-deuterium isotope shift $\left.{ }^{14,18}(0.9 \mathrm{ppm})\right), 10.8$.

\section{$\left(\boldsymbol{S}_{S}, \boldsymbol{S}_{S}, 2 R\right)$-1,1-Bis( $p$-tolylsulfinyl)-2-dec-10-enylcyclopropane $(5)^{14}$} Prepared analogously to $\mathbf{6}$ except aldehyde $\mathbf{S 9}$ was used.

Yield: $1.61 \mathrm{~g}$ (35\% over three steps); clear oil; $R_{f}=0.35(20 \%$, EtOAc/toluene, $\left.\mathrm{KMnO}_{4}, \mathrm{UV}\right)$.

${ }^{1} \mathrm{H}$ NMR $\left(\mathrm{CDCl}_{3}, 400 \mathrm{MHz}\right): \delta=7.58\left(\mathrm{~d},{ }^{3} \mathrm{~J}=8.0 \mathrm{~Hz}, 2 \mathrm{H}\right), 7.37\left(\mathrm{~d},{ }^{3} \mathrm{~J}=\right.$ $8 \mathrm{~Hz}, 2 \mathrm{H}$ ), 7.23 (d, ${ }^{3} \mathrm{~J}=8 \mathrm{~Hz}, 2 \mathrm{H}$ ), 7.07 (d, ${ }^{3} \mathrm{~J}=8.0 \mathrm{~Hz}, 2 \mathrm{H}$ ), 5.81 (ddt, $\left.{ }^{3} J=17.2,10.4,6.4 \mathrm{~Hz}, 1 \mathrm{H}\right), 5.03-4.92(\mathrm{~m}, 2 \mathrm{H}), 2.49(\mathrm{~s}, 3 \mathrm{H}), 2.41(\mathrm{~s}$, $3 \mathrm{H}), 2.05\left(\mathrm{q},{ }^{3} \mathrm{~J}=6.8 \mathrm{~Hz}, 2 \mathrm{H}\right), 1.80-1.62(\mathrm{~m}, 2 \mathrm{H}), 1.40-1.25(\mathrm{~m}, 11 \mathrm{H})$.
$\left(S_{S}\right)$-1-p-Tolylsulfinyl-(1R,2R)-2-d-2-(non-8-en-1-yl)-1-(8,8,8- $d_{3}-$ octyl)cyclopropane (18)

Prepared analogously to $\mathbf{1 6 .}$

Yield: $1.61 \mathrm{~g}$ (64\%); clear oil; $R_{f}=0.29\left(30 \%, \mathrm{Et}_{2} \mathrm{O} / \mathrm{hexanes,} \mathrm{UV,} \mathrm{KM-}\right.$ $\left.\mathrm{nO}_{4}\right) ;[\alpha]_{\mathrm{D}}^{23}=+57.27\left(c=0.220, \mathrm{CHCl}_{3}\right)$.

FTIR (NaCl plate): 2925, 2854, 2360, 1640, 1492, $1464 \mathrm{~cm}^{-1}$.

${ }^{1} \mathrm{H}$ NMR $\left(\mathrm{CDCl}_{3}, 400 \mathrm{MHz}\right): \delta=7.50\left(\mathrm{~d},{ }^{3} \mathrm{~J}=8.0 \mathrm{~Hz}, 2 \mathrm{H}\right), 7.29\left(\mathrm{~d},{ }^{3} \mathrm{~J}=\right.$ $8.0 \mathrm{~Hz}, 2 \mathrm{H}$ ), 5.81 (ddt, $\left.{ }^{3} \mathrm{~J}=17.2,10.4,6.4 \mathrm{~Hz}, 1 \mathrm{H}\right), 5.04-4.87(\mathrm{~m}, 2 \mathrm{H})$, $2.41(\mathrm{~s}, 3 \mathrm{H}), 2.03$ (q, $3 \mathrm{~J}=7.6 \mathrm{~Hz}, 2 \mathrm{H}), 1.65-1.45$ (m, $3 \mathrm{H}), 1.44-1.05$ $(\mathrm{m}, 25 \mathrm{H}), 0.42\left(\mathrm{t},{ }^{2} J=6.4 \mathrm{~Hz}, 1 \mathrm{H}\right)$.

${ }^{13} \mathrm{C}$ NMR $\left(\mathrm{CDCl}_{3}, 100 \mathrm{MHz}\right): \delta=141.4,139.8,139.1,129.5,125.1$, $114.2,44.4,33.8,31.8,29.8,29.4,29.4,29.3,29.3,29.2,29.0,28.9$, $28.3,27.4,26.2,22.4,21.4,18.8,14.7,13.2\left(\mathrm{C} 8\right.$, quin, ${ }^{1} J_{\mathrm{CD}}=18.0 \mathrm{~Hz}$, upfield $\alpha$-deuterium isotope shift $\left.{ }^{14,18}(0.9 \mathrm{ppm})\right)$.

(1R,2S)-1-(Non-8-en-1-yl)-2-2-d -(8,8,8-d - $_{\mathbf{3}}$-ctyl)cyclopropane (21) A $t$-BuLi solution in pentane $(0.75 \mathrm{~mL}, 1.5 \mathrm{M}, 0.5 \mathrm{mmol})$ was added in one portion (as quickly and safely as possible) to a stirred solution of sulfoxide 18 ( $151.3 \mathrm{mg}, 0.36 \mathrm{mmol})$ in toluene $(7.1 \mathrm{~mL})$ at $-78{ }^{\circ} \mathrm{C}$. The reaction was stirred for 10 seconds before quenching with MeOD ( 1 $\mathrm{mL}$ ) in one portion; the mixture was then warmed to $0{ }^{\circ} \mathrm{C}$ and stirred for $1 \mathrm{~h}$. Saturated $\mathrm{NH}_{4} \mathrm{Cl}(10 \mathrm{~mL})$ was then added, the layers were separated and the aqueous layer was extracted with $\mathrm{Et}_{2} \mathrm{O}(3 \times 10 \mathrm{~mL})$. The combined organic layers were dried over anhydrous $\mathrm{MgSO}_{4}$, filtered, and concentrated to afford a crude oil $(0.30 \mathrm{~g})$. The oil was the purified by FCC (100\%, HPLC grade hexanes) to afford 21.

Yield: $93.1 \mathrm{mg}\left(90 \%, 84 \% \mathrm{D}\right.$ at $\left.\mathrm{C}_{10}\right)$; colourless oil; $R_{f}=0.92$ (100\% hexanes, $\left.\mathrm{I}_{2}, \mathrm{KMnO}_{4}\right) ;[\alpha]_{\mathrm{D}}^{22}=+2.041\left(c=0.392, \mathrm{CHCl}_{3}\right)$.

FTIR (NaCl plate): 3076, 3060, 2989, 2912, 2856, 1641, 1464, 992, $909 \mathrm{~cm}^{-1}$.

${ }^{1} \mathrm{H} \mathrm{NMR}\left(\mathrm{CDCl}_{3}, 400 \mathrm{MHz}\right): \delta=5.82\left(\mathrm{ddt},{ }^{3} \mathrm{~J}=17.2,10.4,6.8 \mathrm{~Hz}, 1 \mathrm{H}\right)$, 5.05-4.90 (m, $2 \mathrm{H}), 2.04\left(\mathrm{q},{ }^{3} \mathrm{~J}=7.6 \mathrm{~Hz}, 2 \mathrm{H}\right), 1.45-1.10(\mathrm{~m}, 26 \mathrm{H})$, $0.71-0.58(\mathrm{~m}, 1 \mathrm{H}), 0.58-0.51(\mathrm{~m}, 1 \mathrm{H}),-0.34(\mathrm{t}, J=4.4 \mathrm{~Hz}, 1 \mathrm{H})$.

${ }^{13} \mathrm{C} \mathrm{NMR}\left(\mathrm{CDCl}_{3}, 100 \mathrm{MHz}\right): \delta=139.3,114.1,33.8,31.8,30.2,29.7$, 29.6, 29.5, 29.4, 29.2, 29.0, 28.7, 28.6, 22.4, 15.7 (C2, upfield $\beta$-deuterium isotope $\left.\operatorname{shift}^{18}(0.1 \mathrm{ppm})\right), 15.4\left(\mathrm{C} 1, \mathrm{t},{ }^{1} J_{\mathrm{CD}}=23.0 \mathrm{~Hz}\right.$, upfield $\alpha$ deuterium isotope $\left.\operatorname{shift}^{18}(0.4 \mathrm{ppm})\right), 13.2\left(\mathrm{C} 8, \mathrm{t},{ }^{1} J_{\mathrm{CD}}=19.0 \mathrm{~Hz}\right.$, upfield $\alpha$-deuterium isotope $\left.\operatorname{shift}^{18}(0.9 \mathrm{ppm})\right), 10.8$.

\section{(9R,10S)-9-d-Dihydrosterculic Acid (4)}

This protocol was adapted from the procedure reported by Kitahara. ${ }^{30}$ Crude ester S10 (137.8 mg, $0.44 \mathrm{mmol}$ if pure) and $\mathrm{LiOH} \cdot \mathrm{H}_{2} \mathrm{O}(186.3$ $\mathrm{mg}, 4.4 \mathrm{mmol})$ were dissolved in $\mathrm{MeOH}(14.5 \mathrm{~mL})$ and heated to reflux for $15 \mathrm{~h}$. The resulting reaction mixture was allowed to cool to ambient temperature before acidifying with $1 \mathrm{M} \mathrm{HCl}(5 \mathrm{~mL})$ and concentrating under reduced pressure to remove the $\mathrm{MeOH}$. EtOAc $(15 \mathrm{~mL})$ was added and the layers were separated. The aqueous layer was extracted with EtOAc $(3 \times 10 \mathrm{~mL})$, and the combined organic layers were dried over anhydrous $\mathrm{Na}_{2} \mathrm{SO}_{4}$, filtered and concentrated to give a crude pale-brown oil (120.5 mg). The crude oil was purified by FCC ( $9 \% \mathrm{EtOAc} / 1 \% \mathrm{AcOH} /$ hexanes) to afford acid 4.

Yield: $102 \mathrm{mg}$ (85\% over two steps, $98 \%$ D at $\mathrm{C}_{9}$ ); $R_{f} 0.20$ (9\% EtOAc/1\% AcOH/ hexanes, $\mathrm{I}_{2}, \mathrm{KMnO}_{4}$ ).

FTIR (NaCl plate): 3057, 2924, 2854, 2676, 2213, 1711, 1465, 1413 , $1285,936 \mathrm{~cm}^{-1}$.

${ }^{1} \mathrm{H} \mathrm{NMR}\left(\mathrm{CDCl}_{3}, 300 \mathrm{MHz}\right): \delta=10.98(\mathrm{br} \mathrm{s}, 1 \mathrm{H}), 2.35\left(\mathrm{t},{ }^{3} \mathrm{~J}=7.2 \mathrm{~Hz}\right.$, $2 \mathrm{H}$ ), 1.64 (quin, $\left.{ }^{3} \mathrm{~J}=7.2 \mathrm{~Hz}, 2 \mathrm{H}\right), 1.45-1.21(\mathrm{~m}, 22 \mathrm{H}), 1.19-1.05(\mathrm{~m}$, $2 \mathrm{H}), 0.69-0.61(\mathrm{~m}, 1 \mathrm{H}), 0.57-0.53(\mathrm{~m}, 1 \mathrm{H}),-0.34\left(\mathrm{t},{ }^{3} \mathrm{~J}=4.5 \mathrm{~Hz}, 1 \mathrm{H}\right)$. 
${ }^{13} \mathrm{C}$ NMR $\left(\mathrm{CDCl}_{3}, 75 \mathrm{MHz}\right): \delta=179.9,34.0,31.9,30.2,30.1,29.7,29.4$, 29.4, 29.3, 29.1, 28.7, 28.5, 24.7, 22.4, 15.7, 15.3 (C9, t, ${ }^{1} J_{\mathrm{CD}}=23.6 \mathrm{~Hz}$, upfield $\alpha$-deuterium isotope shift $\left.{ }^{18}(0.4 \mathrm{ppm})\right), 13.2\left(\mathrm{C} 19, \mathrm{t},{ }^{1} J_{\mathrm{CD}}=\right.$ $19.0 \mathrm{~Hz}$, upfield $\alpha$-deuterium isotope $\left.\operatorname{shift}^{18}(0.9 \mathrm{ppm})\right), 10.8$.

\section{(9R,10S)-10-d-Dihydrosterculic Acid (3)}

Prepared analogously to 4 .

Yield: $43 \mathrm{mg}$ (54\%); light-yellow solid; $R_{f}=0.20$ (9\% EtOAc/1\% AcOH/ hexanes, $\left.\mathrm{I}_{2}, \mathrm{KMnO}_{4}\right)$.

FTIR ( $\mathrm{NaCl}$ plate): 3057, 2924, 2854, 2676, 2213, 1711, 1465, 1413 , $1285,936 \mathrm{~cm}^{-1}$.

${ }^{1} \mathrm{H} \mathrm{NMR}\left(\mathrm{CDCl}_{3}, 300 \mathrm{MHz}\right): \delta=10.98($ br s, $1 \mathrm{H}), 2.35\left(\mathrm{t},{ }^{3} \mathrm{~J}=7.2 \mathrm{~Hz}\right.$, $2 \mathrm{H}$ ), 1.64 (quin, $\left.{ }^{3} \mathrm{~J}=7.2 \mathrm{~Hz}, 2 \mathrm{H}\right), 1.45-1.21(\mathrm{~m}, 22 \mathrm{H}), 1.19-1.05(\mathrm{~m}$, $2 \mathrm{H}), 0.69-0.61(\mathrm{~m}, 1 \mathrm{H}), 0.57-0.53(\mathrm{~m}, 1 \mathrm{H}),-0.34\left(\mathrm{t},{ }^{3} \mathrm{~J}=4.5 \mathrm{~Hz}, 1 \mathrm{H}\right)$. ${ }^{13} \mathrm{C} \mathrm{NMR}\left(\mathrm{CDCl}_{3}, 75 \mathrm{MHz}\right): \delta=180.0,34.0,31.9,30.2,30.1,29.7,29.4$, 29.4, 29.3, 29.1, 28.7, 28.5, 24.7, 22.4, 15.62, 15.4 (C10, t, ${ }^{1} \mathrm{~J}=23.6 \mathrm{~Hz}$, upfield $\alpha$-deuterium isotope $\left.\operatorname{shift}^{18}(0.3 \mathrm{ppm})\right), 13.3\left(\mathrm{C} 19, \mathrm{t},{ }^{1} \mathrm{~J}=\right.$ $19.0 \mathrm{~Hz}$, upfield $\alpha$-deuterium isotope $\left.\operatorname{shift}^{18}(0.8 \mathrm{ppm})\right), 10.8$.

\section{Funding Information}

This research was supported by a Natural Sciences and Engineering Research Council of Canada (NSERC) Discovery Grant (P.H.B.), an NSERC Research Tools and Instrument Grant (P.H.B. and J.M.M.), the Canada Foundation for Innovation Leaders Opportunity Fund (J.M.M.) and Carleton University (J.M.M.).

\section{Acknowledgment}

The authors thank Prof. Jeffrey Smith (Carleton University) for assistance with high-resolution mass spectrometry.

\section{Supporting Information}

Experimental procedures, spectral data, copies of ${ }^{1} \mathrm{H}$ NMR and ${ }^{13} \mathrm{C}$ NMR spectra are available.Supporting information for this article is available online at https://doi.org/10.1055/s-0036-1591976.

\section{References}

(1) (a) Christie, W. W. In Topics in Lipid Chemistry; Gunstone, F. D., Ed.; Wiley: New York, 1970, 1. (b) Smith, C. R.; Wilson, T. L.; Mikolajczak, K. L. Chem. Ind. (London) 1961, 256. (c) Kleiman, R.; Earle, F. R.; Wolff, I. A. Lipids 1969, 4, 317. (d) Jie, L. K.; Marcel, S. F.; Chan, M. F. J. Chem. Soc., Chem. Commun. 1977, 78. (e) Vickery, J. R. J. Am. Oil Chem. Soc. 1980, 57, 87. (f) Berry, S. K. Lipids 1980, 15, 452. (g) Ralaimanarivo, A.; Gaydou, E. M.; Bianchini, J. P. Lipids 1982, 17, 1. (h) Fisher, G. S.; Cherry, J. P. Lipids 1983, 18, 589. (i) Razafimamonjison, G.; Leong Pock Tsy, J. M.; Randriamiarinarivo, M.; Ramanoelina, P.; Rasoarahona, J.; Fawbush, F.; Danthu, P. Chem. Biodivers. 2017, 14, e1600441. (j) For a recent application of cyclopropane fatty acids in the detection of labeling fraud in cheese, see: Caligiani, A.; Nocetti, M.; Lolli, V.; Marseglia, A.; Palla, G. J. Agric. Food Chem. 2016, 64, 4158.

(2) (a) Buist, P. H. Nat. Prod. Rep. 2004, 21, 249. (b) Buist, P. H. Tetrahedron: Asymmetry 2004, 15, 2779. (c) Buist, P. H. Nat. Prod. Rep. 2007, 24, 1110.
(3) Wang, H.; Klein, M. G.; Zou, H.; Snell, G.; Levin, I.; Li, K.; Sang, B.C. Nat. Struct. Mol. Biol. 2015, 22, 581.

(4) Bai, Y.; McCoy, J. G.; Levin, E. J.; Sobrado, P.; Rajashankar, K. R.; Fox, B. G.; Zhou, M. Nature 2015, 524, 252.

(5) (a) Paton, C. M.; Vaughan, R. A.; Selen-Alpergin, E. S.; AssadiPorter, F.; Dowd, M. K. Nutr. Res. (N. Y., NY, U. S.) 2017, 45, 52. (b) Gutiérrez-Juárez, R.; Pocai, A.; Mulas, C.; Ono, H.; Bhanot, S.; Molina, B. P.; Rosetti, L. J. Clin. Invest. 2006, 116, 1686.

(6) (a) Ntambi, J. M.; Miyazaki, M.; Stoehr, J. P. Lan H.; Kendziorski, C. M. Yandell B. S.; Song, Y.; Cohen, P.; Friedman, J. M.; Attie, A. D. Proc. Natl. Acad. Sci. USA 2002, 99, 11482. (b) Flowers, M. T.; Ntambi, J. M. Curr. Opin. Lipidol. 2008, 19, 248.

(7) Stefan, N.; Peter, A.; Cegan, A.; Staiger, H.; Machann, J.; Schick, F.; Claussen, C. D.; Fritsche, A.; Häring, H.-U.; Schleicher, E. Diabetologia 2008, 51, 648 .

(8) Dobrzyn, A.; Ntambi, J. M. Obes. Rev. 2005, 6, 169.

(9) (a) Theodoropoulos, P. C.; Gonzales, S. S.; Winterton, S. E.; Rodriguez-Navas, C.; McKnight, J. S.; Morlock, L. K.; Hanson, J. M.; Cross, B.; Own, A. E. Duan Y.; Moreno, J. R.; Lemoff, A.; Mirzaei, H.; Posner, B. A.; Williams, N. S.; Ready, J. M.; Nijhawan, D. Nat. Chem. Biol. 2016, 12, 218. (b) Peck, B.; Schulze, A. FEBS J. 2016, 283, 2767. (c) Igal, R. A. Biochim. Biophys. Acta, Mol. Cell Biol. Lipids 2016, 1865. (d) Morgan-Lappe, S. E.; Tucker, L. A.; Huang, X.; Zhang, Q.; Sarthy, A. V.; Zakula, D.; Vernetti, L.; Schurdak, M.; Wang, J.; Fesik, S. W. Cancer Res. 2007, 67, 4390.

(10) (a) Zhang, Z.; Dales, N. A.; Winther, M. D. J. Med. Chem. 2014, 57, 5039. (b) Imamura, K.; Tomita, N.; Kawakita, Y.; Ito, Y.; Ono, K.; Nii, N.; Miyazaki, T.; Yonemori, K.; Tawada, M.; Sumi, H.; Satoh, Y.; Yamamoto, Y.; Miyahisa, I.; Sasaki, M.; Satomi, Y.; Mirayama, M.; Nishigaki, R.; Maezaki, H. Bioorg. Med. Chem. 2017, 25, 3768. (c) Kurihara, A.; Okano, F. PCT Int. Appl. WO 2017150595 A1, 2017.

(11) (a) Lee, M.; Lenman, M.; Banas, A.; Bafor, M.; Singh, S.; Schweizer, M.; Nilsson, R.; Liljenberg, C.; Dahlqvist, A.; Gummeson, P.; Sjödahl, S.; Green, A.; Stymne, S. Science 1998, 282, 1315. (b) Reed, D. W.; Polichuk, D. R.; Buist, P. H.; Ambrose, S. J.; Sasata, R. J.; Savile, C. K.; Ross, A. R. S.; Covello, P. S. J. Am. Chem. Soc. 2003, 125, 10635. (c) Zhu, X.; Shieh, P.; Su, M.; Bertozzi, C. R.; Zhang, W. Chem. Commun. 2016, 11239.

(12) (a) Buist, P. H.; Marecak, D. M. J. Am. Chem. Soc. 1992, 114, 5073. (b) Buist, P. H.; Behrouzian, B. J. Am. Chem. Soc. 1996, 118, 6295. (c) Buist, P. H.; Behrouzian, B. J. Am. Chem. Soc. 1998, 120, 871. (d) Meesapyodsuk, D.; Reed, D. W.; Savile, C. K.; Buist, P. H.; Covello, P. S. Biochemistry 2000, 39, 11948. (e) Fauconnot, L.; Buist, P. H. J. Org. Chem. 2001, 66, 1210. (f) Savile, C. K.; Fabriàs, G.; Buist, P. H. J. Am. Chem. Soc. 2001, 123, 4382. (g) Behrouzian, B.; Fauconnot, L.; Daligault, F.; Nugier-Chauvin, C.; Patin, H.; Buist, P. H. Eur. J. Biochem. 2001, 268, 3545. (h) Behrouzian, B.; Savile, C. K.; Dawson, B.; Buist, P. B.; Shanklin, J.J. Am. Chem. Soc. 2002, 124, 3277. (i) Fauconnot, L.; Buist, P. H. Bioorg. Med. Chem. Lett. 2001, 11, 2879. (j) Reed, D. W.; Savile, C. K.; Qui, X.; Buist, P. H.; Covello, P. S. Eur. J. Biochem. 2002, 269, 5024. (k) Serra, M.; Gauthier, L. T.; Fabrias, G.; Buist, P. H. Insect Biochem. Mol. Biol. 2006, 36, 822. (1) Whittle, E. J.; Tremblay, A. E.; Buist, P. H.; Shanklin, J. Proc. Natl. Acad. Sci. USA 2008, 105, 14738. (m) Bhar, P.; Reed, D. W.; Covello, P. S.; Buist, P. H. Angew. Chem. Int. Ed. 2012, 51, 6686.

(13) (a) Buist, P. H.; MacLean, D. B. Can. J. Chem. 1981, 59, 828. (b) Buist, P. H.; MacLean, D. B. Can. J. Chem. 1982, 60, 371. (c) Buist, P. H.; Findlay, J. M. Can. J. Chem. 1984, 63, 971. (d) Buist, P. H.; Pon, R. A. J. Org. Chem. 1990, 55, 6240. (e) Stuart, L. J.; Buck, J. P.; Tremblay, A. E.; Buist, P. H. Org. Lett. 2006, 8, 79. 
(14) Palko, J. W.; Buist, P. H.; Manthorpe, J. M. Tetrahedron: Asymmetry 2013, 24, 165.

(15) For other asymmetric syntheses of cyclopropane fatty acids, see: (a) Coxon, G. D.; Al-Dulayymi, J. R.; Baird, M. S.; Knobl, S.; Roberts, E.; Minnikin, D. E. Tetrahedron: Asymmetry 2003, 14, 1211. (b) Lou, Y.; Horikawa, M.; Kloster, R. A.; Hawryluk, N. A.; Corey, E. J. J. Am. Chem. Soc. 2004, 126, 8916. (c) Shah, S.; White, J. M.; Williams, S. J. Org. Biomol. Chem. 2014, 12, 9427.

(16) (a) Farhat, S.; Marek, I. Angew. Chem. Int. Ed. 2002, 41, 1410. (b) Farhat, S.; Zouev, I.; Marek, I. Tetrahedron 2004, 60, 1329. (c) Chinkov, N.; Majumdar, S.; Marek, I. J. Am. Chem. Soc. 2002, 124, 10282. (d) Chinkov, N.; Majumdar, S.; Marek, I. J. Am. Chem. Soc. 2003, 125, 13258. (e) Chinkov, N.; Chechik, H.; Majumdar, S.; Marek, I. Synthesis 2002, 2473. (f) Sklute, G.; Marek, I. J. Am. Chem. Soc. 2006, 128, 4642. (g) Liard, A.; Marek, I. J. Org. Chem. 2000, 65, 7218. (h) Satoh, T. Chem. Rev. 1996, 96, 3303. (i) Satoh, T.; Itoh, N.; Watanabe, H.; Koide, H.; Matsuno, H.; Matsuda, K.; Yamakawa, K. Tetrahedron 1995, 51, 9327. (j) Satoh, T.; Hanaki, N.; Kumarochi, Y.; Inoue, Y.; Hosaya, K.; Sakai, K. Tetrahedron 2002, 58, 2533. (k) Satoh, T.; Yamada, N.; Asano, T. Tetrahedron Lett. 1998, 39, 6935.

(17) Abramovitch, A.; Fensterbank, L.; Malacria, M.; Marek, I. Angew. Chem. Int. Ed. 2008, 47, 6865.

(18) Palko, J. W. Enantioselective Synthesis of (9R,10S)-Dihydrosterculic Acid: Overcoming Unanticipated Challenges in $\alpha, \beta$-Unsaturated 1,1-bis(Sulfoxides); M.Sc. Thesis: Carleton University, August 2012.

(19) Shields, S. W. J. Part A: Enantioselective Synthesis of C9 and C10 Deuterio-Labelled Dihydrosterculic Acids. Part B: Efficient, and Scalable Preparation of bis(Deuterium)- and ${ }^{13} \mathrm{C}$-Labelled Diazomethane; M.Sc. Thesis: Carleton University, September 2014.

(20) Mihailescu, M.; Vaswani, R. G.; Jardón-Valadez, E.; CastroRomán, F.; Freites, J. A.; Worcester, D. L.; Chamberlin, A. R.; Tobias, D. J.; White, S. H. Biophys. J. 2011, 100, 1455.

(21) Toledo, H.; Pisarevsky, E.; Abramovitch, A.; Szpilman, A. M. Chem. Commun. 2013, 4367.
(22) Yoshida, Y.; Sakakura, Y.; Aso, N.; Okada, S.; Tanabe, Y. Tetrahedron 1999, 55, 2183.

(23) Despite the absence of a chelating group, tertiary cyclopropyllithium species such as $\mathbf{1 9}$ have been shown to be configurationally stable. See references 14 and 17, as well as (a) Corey, E. J.; Eckrich, T. M. Tetrahedron Lett. 1984, 25, 2415. (b) Piers, E.; Coish, P. Synthesis 1995, 47. (c) Isono, N.; Mori, M. J. Org. Chem. 1996, 61, 7867. (d) Lautens, M.; Delanghe, P. H. M. J. Org. Chem. 1992, 57, 798. (e) Piers, E.; Jean, M.; Marrs, P. S. Tetrahedron Lett. 1987, 28, 5075.

(24) Orthometallation as the proton source is supported by noninteger integration of $t$-butyl $p$-tolyl sulfoxide that was observed in the ${ }^{1} \mathrm{H}$ NMR spectrum of the crude reaction products in the conversion of $\mathbf{1 8}$ to $\mathbf{2 1}$ (See Supporting Information, Figure S29). The authors surmise that non-integer integration of the protons ortho to the sulfinyl group arises via formation of $\mathbf{2 0}$ followed by directed orthometallation by excess $t$-BuLi followed by deuteration. While this evidence is indirect, a similar phenomenon has been previously reported in the lithium-sulfoxide exchange of paracyclophanyl $p$-tolyl sulfoxides. The authors had experimental evidence for orthometallation of $t$-butyl p-tolyl sulfoxide as the proton source; however, these sideproducts were obtained in low to moderate yields, thus not excluding the other possible proton sources proposed herein. See: Parmar, R.; Coles, M. P.; Hitchcock, P. B.; Rowlands, G. J. Synthesis 2010, 4177.

(25) Pedersen, D. S.; Rosenbohm, C. Synthesis 2001, 2431.

(26) Savile, C. K.; Reed, D. W.; Meesapyodsuk, D.; Covello, P. S.; Buist, P. H. J. Chem. Soc., Perkin Trans. 1 2001, 1116.

(27) Gardette, M.; Alexakis, A.; Normant, J. F. Tetrahedron 1985, 41, 5887.

(28) Najera, F.; Delouvrie, B.; Fensterbank, L.; Malacria, M. J. Organomet. Chem. 2002, 644, 130.

(29) Mohammadpoor-Baltork, I.; Moghadam, M.; Tangestaninejad, S.; Mirkhani, V.; Mirjafari, A. C. R. Chim. 2010, 13, 1468.

(30) Motoyoshi, H.; Ishigami, K.; Kitahara, T. Tetrahedron 2001, 57, 3899. 